www.jmscr.igmpublication.org

Impact Factor (SJIF): 6.379

Index Copernicus Value: 79.54

ISSN (e)-2347-176x ISSN (p) 2455-0450

crossrefDOI: https://dx.doi.org/10.18535/jmscr/v6i10.221

\title{
Accuracy of Formulae for Secondary Intraocular Lens Power Calculations in Aphakic Patients
}

\author{
Authors \\ Dr Anirudh Duhan", Dr Nisha V Ahuja ${ }^{2}$ \\ ${ }^{1}$ IOL fellow Sankara Eye Hospital, Anand, Gujarat \\ ${ }^{2}$ Consultant Cornea and Cataract Services Sankara Eye Hospital, Anand, Gujarat, India
}

\section{Introduction}

In general, there are two types of intraocular lens (IOL) calculation formulas: axial length vergence formulas and refractive vergence formulas. ${ }^{1}$ IOL formulas such as Hoffer Q, ${ }^{2}$ Holladay I, ${ }^{3}$ SRK/T, ${ }^{4}$ and SRK II ${ }^{5,6}$ require the measurement of axial length, keratometry, and an IOL constant.

Alternately, refractive vergence formulas do not require axial length measurements, instead, they require the preoperative refraction and manufacturer's IOL constant to calculate IOL power. Refractive vergence formulas assume that the patient has clear media and that no power, e.g. lens, will be removed. ${ }^{1}$

Refractive vergence formulas are suitable for phakic IOLs, secondary IOLs for aphakia as in this study, and piggyback lenses for pseudophakia.

Refractive vergence formulas include Lanchulev, ${ }^{7}$ Holladay R, ${ }^{8}$ Khan, ${ }^{9}$ and Mackool. ${ }^{10}$

This study compares mean of the difference between predicted post operative refraction values and actual post operative refraction values of Axial length vergence formula versus refractive vergence formula.

\section{Methods}

This is a prospective, non randomized study, evaluating 60 eyes of 60 patients aged 60 years and above who underwent secondary iol implantation at Sankara Eye Hospital, Anand, Gujarat over a period of 6 months(April 2018 to September 2018).30 patients were fitted with IOL powers calculated using SRK-T formula and 30 with Mackool's formula.

Patients aged 60 years and above who were aphakic post- cataract extraction underwent posterior iris claw lens implantation. Only patients left aphakic due to some intraoperative complications without any pre-existing ocular comorbidities during the $1^{\text {st }}$ surgery were included.

Aphakia accompanied with pre-existing ocular conditions, traumatic aphakia were not included in this study.

Axial length was measured with contact A-scan (BIOMEDIX ECHORULE 2) and its built in calculator was used to calculate IOL power with SRK/T.

IOL power was calculated using the formula for MACKOOL.

$\mathrm{IOL}_{\text {Mackool }}=1.75 \times$ Aphakic refraction $+(\mathrm{A}-118.84)$, Where A is the A-constant.

Keratometry was done using TOPCON KR 8900 
auto refractometer.

Since posterior Iris claw lens was implanted, the calculated power by SRK-T was reduced by $0.50 \mathrm{D}$ in each case as the built in calculator did not have A constant for the PMMA iris claw lens. No such deduction was needed in the case of Mackool's.

Predicted refraction for the corresponding IOL was calculated and the absolute difference between the values of predicted and actual post operative refraction on the $1^{\text {st }}$ post-op day was calculated for each case. Any difference of more than $0.50 \mathrm{D}$ was considered clinically significant.

The mean of this difference was calculated for both the formulas, and $\mathrm{p}$ value of the difference between mean of SRK-T formula and Mackool's formula was calculated using unpaired t-test.

\section{Results}

The study group comprised of 60 patients divided into 2 groups (SRK-T and Mackool) of 30 patients each. The mean age of the patients was 73.56.The mean for group $1(\mathrm{SRK}-\mathrm{T})$ was $0.76 \mathrm{D}$ and that for group 2 (Mackoo) was 0.62.D

There was a significant difference $(\mathrm{P}=0.0376)$ between the mean for Mackool's formula (0.76D) and mean for SRK/T(0.62D).

\section{Unpaired t test results}

$P$ value and statistical significance:

The two-tailed $P$ value equals 0.0376

By conventional criteria, this difference is considered to be statistically significant

Confidence interval:

The mean of Group One minus Group Two equals 0.1358300

$95 \%$ confidence interval of this difference: From 0.0080402 to 0.2636198

Intermediate values used in calculations:

$\mathrm{t}=2.1277$

$\mathrm{df}=58$

standard error of difference $=0.064$

\section{Discussion}

In the current study, axial length vergence formula showed statistically significant and clinically important difference as compared to the refractive vergence formula.

Similar difference of $0.8 \mathrm{D}$ was found in the study of Abdel-Hafez. ${ }^{11}$ This outcome may be due to the lower precision of preoperative AR compared to the precision of axial length measurements and keratometry measurements.

The influences of IOL material might be negligible in the current study. This was likely because the variation was too small in lens material and design indicated by the A-constant.

Thus, in case axial length measurement is not possible when refraction is available, Mackool's formula could be used.

\section{References}

1. Holladay J.T. Intraocular lens power calculations for the refractive surgeon J Operat Tech Cataract Refract Surg. 1998;1(3):105-117.

2. Hoffer K.J. The Hoffer Q formula: a comparison of theoretic and regression formulas. J Cataract Refract Surg. 1993; 19(6):700-712. Erratum 1994; 20(6):677.

3. Holladay J.T., Prager T.C., Chandler T.Y., Musgrove K.H., Lewis J.W., Ruiz R.S. A three-part system for refining intraocular lens power calculations. J Cataract Refract Surg. 1988;14(1):17-24.

4. Retzlaff J., Sanders D.R., Kraff M.C. Development of the SRK/T intraocular lens implantation power calculation formula. J Cataract Refract Surg. 1990;16 (3):333-340. Erratum 1990; 16(4):528.

5. Sander D.R., Retzlaff J., Kraff M.C. Comparison of the SRK II formula and other second generation formulas. J Cataract Refract Surg. 1988;14:36-41.

6. Dang M.S., Raj P.P. SRK II formula in the calculation of intraocular lens power. $\mathrm{Br} \mathrm{J}$ Ophthalmol. 1989;73:823-826.

7. Ianchulev T., Salz J., Hoffer K., Albini T., Hsu H., Labree L. Intraoperative optical refractive biometry for intraocular lens power estimation without axial length and keratometry measurements. J Cataract Refract Surg. 2005 Aug;31(8):1530-1536.

8. Holladay J.T. Refractive power calculateons for intraocular lenses in the phakic eye. Am J Ophthalmol 1993;116(1):63-66. 
9. Khan A.O., AlGaeed A. Paediatric secondary intraocular lens estimation from the aphakic refraction alone: comparison with a standard biometric technique. $\mathrm{Br} \mathrm{J}$ Ophthalmol. 2006 Dec;90(12):1458-1460. Epub 2006 Aug 17.

10. Mackool R.J., Ko W., Mackool R. Intraocular lens power calculation after laser in situ keratomileusis: aphakic refraction technique. J Cataract Refract Surg. 2006 Mar;32(3):435-437.

11. Abdel-Hafez G., Trivedi R.H., Wilson M.E., Bandyopadhyay D. Comparison of aphakic refraction formulas for secondary in-the-bag intraocular lens power estimation in children. J AAPOS. 2011;15(5):432-434. 